Proceedings of the International Conference on Oxide Materials for Electronic Engineering, May 29-June 2, 2017, Lviv

\title{
Sorption of Neodymium and Gadolinium on Transcarpathian Clinoptilolite
}

\author{
V.O. Vasylechko ${ }^{a, b}$, E.T. Stechynska ${ }^{a}$, O.D. Stashikiv ${ }^{a *}$, G.V. Gryshchouk ${ }^{a}$ \\ AND I.O. PATSAY ${ }^{a}$ \\ ${ }^{a}$ Ivan Franko National University of Lviv, 6 Kyryla and Mephodia Str., 79005 Lviv, Ukraine \\ ${ }^{b}$ Lviv University of Trade and Economics, 9 Samchuka Str., 79011 Lviv, Ukraine
}

\begin{abstract}
The sorption properties of Transcarpathian clinoptilolite towards $\mathrm{Nd}(\mathrm{III})$ and Gd(III) under dynamic condition have been studied. $\mathrm{Nd}(\mathrm{III})$ was sorbed with the best efficiency on the uncalcined clinoptilolite samples from the solutions at $\mathrm{pH}$ 6.5. Clinoptilolite samples that were previously calcined at $250^{\circ} \mathrm{C}$ exhibit the maximal sorption capacity towards $\mathrm{Gd}(\mathrm{III})$ from the solutions at $\mathrm{pH}$ 9.5. Nd(III) and Gd(III) sorption on clinoptilolite mechanisms are different: $\mathrm{Nd}(\mathrm{III})$ is sorbed according to the ion-exchange mechanism, and the sorption of Gd(III) is carried out mainly by means of the adsorption of soluble hydrolyzed forms of Gd(III) on the zeolite surface. The differences in sorption mechanisms of these lanthanides give an opportunity to separate $\mathrm{Nd}$ (III) and Gd(III) from the solutions at pH 9.5. The maximal sorption capacity of the clinoptilolite regarding Nd(III) and Gd(III) at the optimal conditions was found to be 1810 and $6500 \mu \mathrm{g} / \mathrm{g}$. The best desorbent of $\mathrm{Nd}$ from the clinoptilolite is $7 \mathrm{M} \mathrm{HNO}_{3}$ solution. The best desorbent of $\mathrm{Gd}$ is $1 \mathrm{M}$ solution of $\mathrm{KCl}$ acidified to $\mathrm{pH} 2.6$, which provides a $100 \%$ withdrawal of $\mathrm{Gd}$ from the zeolite matrix. Transcarpathian clinoptilolite is proposed as a sorbent for the preconcentration of trace amounts of $\mathrm{Nd}(\mathrm{III})$ and $\mathrm{Gd}(\mathrm{III})$ from aqueous solutions in a solid phase extraction mode.
\end{abstract}

DOI: 10.12693/APhysPolA.133.794

PACS/topics: $68.43 .-\mathrm{h}, 07.60 . \mathrm{Dq}, 82.75 . \mathrm{Vx}$

\section{Introduction}

Neodymium and gadolinium are ones of the most popular elements of cerium and yttrium subgroups, respectively. These lanthanides (Ln) have been widely used in the electronics, nuclear power, as components of magnetic alloys, phosphors, hydrogen accumulators, and data storage media. The zeolite compositions with these REE have the biological activity.

Most of the lanthanides (Ln) are closely similar in their chemical properties that causes difficulties in separation and quantitative determination of these elements. The number of highly sensitive and selective methods of analysis for the detection and quantitative determination of Ln is not enough. In most cases, the quantitative determination methods include the pretreatment procedure of samples such as separation, concentration and removal of REE. There is also a problem with the withdrawal of rare metals from the technological solutions.

Solid-phase extraction with the application of different sorbents is one of the ways to solve the pretreatment problem of the technological solutions and wastewaters. More often natural zeolites are used for this purpose, which have several advantages in comparison with other sorbents. For example, these natural aluminosilicates have mechanical strength, good stability in aggressive medium and under thermal treatment, ability to sorb the trace amounts of analytes, high sorption capacity and

*corresponding author; e-mail: olgastashkiv@ukr.net selectivity, possibility of easy modification and regeneration of the sorbent, low cost and accessibility.

Sorption properties of zeolites in aqueous solutions of $\mathrm{Nd}(\mathrm{III})$ and $\mathrm{Gd}(\mathrm{III})$ are investigated insufficiently. There are known works [1-4], in which compositions $\mathrm{Nd}-\mathrm{Gd}-$ synthetic zeolite were studied. Sorption of Ln in most cases was carried out from their nitric of chloride solutions. However, synthetic zeolites are not applied in order to concentrate trace amounts of Nd and Gd. Usually synthetic zeolites containing $\mathrm{Nd}$ and $\mathrm{Gd}$ are investigated in terms of their luminescent properties. Among natural zeolites only heulandite was studied as a sorbent for $\mathrm{Nd}(\mathrm{III})[5,6] . \mathrm{Nd}(\mathrm{III})$ is sorbed on heulandite from the neutral solutions. The sorption capacity of this natural zeolite towards $\mathrm{Nd}(\mathrm{III})$ is not high, also the completeness of the withdrawal of $\mathrm{Nd}$ (III) from solutions is not provided. Particularly, heulandite withdraws only 55\% of $\mathrm{Nd}(\mathrm{III})$ from solutions with the concentration of this Ln $10 \mathrm{mg} / \mathrm{l}[6]$.

The aim of this paper is to examine the influence of various factors $(\mathrm{pH}$, preliminary thermal treatment of sorbent, nature of the buffer solution) on sorption of $\mathrm{Nd}(\mathrm{III})$ and Gd(III) on Transcarpathian clinoptilolite and to investigate the possibility of application of this sorbent in solid phase extraction.

\section{Materials and experimental details}

The clinoptilolite used in this investigation was obtained from the deposit near the village of Sokirnytsia in Ukrainian Transcarpathian region. The previous analysis has shown that the main component was present 
at $85-90 \%$, the specific surface area, determined by water sorption was $59 \mathrm{~m}^{2} / \mathrm{g}$ [7]. The chemical composition of Transcarpathian clinoptilolite is (in \%): $\mathrm{SiO}_{2}, 67.29$; $\mathrm{TiO}_{2}, 0.26 ; \mathrm{Al}_{2} \mathrm{O}_{3}, 12.32 ; \mathrm{Fe}_{2} \mathrm{O}_{3}, 1.26 ; \mathrm{FeO}, 0.25 ; \mathrm{MgO}$, 0.99; $\mathrm{CaO}, 3.01 ; \mathrm{Na}_{2} \mathrm{O}, 0.66 ; \mathrm{K}_{2} \mathrm{O}, 2.76 ; \mathrm{H}_{2} \mathrm{O}, 10.90$ [8].

The zeolite samples were grained in a ball-mill, after that the grain fraction of size $0.20-0.31 \mathrm{~mm}$ was selected, washed with distilled water and dried at room temperature. The thermal treatment of clinoptilolite was performed for $2.5 \mathrm{~h}$ at required temperature in the oven.

The sorption properties of clinoptilolite were studied under dynamic conditions in a solid phase extraction mode. Metal solutions were passed through a sorption cartridge filled with $0.6 \mathrm{~g}$ of the sorbent at $5 \mathrm{ml} / \mathrm{min}$ velocity using the peristaltic pump. The methods of investigation under dynamic conditions are described in detail in [9]. The passage moment of $\mathrm{Nd}(\mathrm{III})$ and $\mathrm{Gd}(\mathrm{III})$ ions was fixed by the photometric method by means of the reaction of $\operatorname{Ln}(\mathrm{III})$ with sulfarsazene. It is a highly sensitive method of $\mathrm{Nd}(\mathrm{III})$ and $\mathrm{Gd}(\mathrm{III})$ determination $(\mathrm{LDL}=100 \mathrm{ng} / \mathrm{ml})$. This makes it possible to establish the passing moment visually and/or by means of a $\mathrm{DR} / 4000 \mathrm{~V}$ spectrophotometer $(\mathrm{HACH})$ at a wavelength of $540 \mathrm{~nm}$.

In order to recover the sorbed $\mathrm{Nd}$ and $\mathrm{Gd}$ from the zeolite bed, $15 \mathrm{ml}$ of an eluent at a flow rate of $1 \mathrm{ml} / \mathrm{min}$ (desorption of $\mathrm{Nd}$ ) and $0.5 \mathrm{ml} / \mathrm{min}$ (desorption of $\mathrm{Gd}$ ) were passed through the sorption cartridge. The eluates were collected in the volumetric flasks of $25 \mathrm{ml}$ and madeup to the mark with double distilled water.

As solutions of mineral acids or acidified solutions of alkaline metals salts are effective desorbents of $\mathrm{Nd}$ and $\mathrm{Gd}$ from the clinoptilolite, solution obtained during the desorption of Ln contain much higher concentrations of metals present in the sorbent composition than matrix solutions obtained during the sorption of $\operatorname{Ln}(\mathrm{III})$ on clinoptilolite. This is the reason why the selectivity of the spectrophotometric determination of $\operatorname{Ln}(\mathrm{III})$ with sulfarsazene proved to be not enough for the analysis of filtrates obtained during the desorption. That is why to determine the content of the desorbed $\mathrm{Nd}(\mathrm{III})$ and $\mathrm{Gd}(\mathrm{III})$ in the solution we applied a spectrophotometric method based on the arsenazo III, which despite the lack of sensitivity is much more selective than the method with the application of sulfarsazene. In order to eliminate the interfering influence of $\mathrm{Fe}^{3+}, \mathrm{Al}^{3+}, \mathrm{Mg}^{2+}$, and $\mathrm{Ca}^{2+}$ ascorbic and sulfosalicylic acids, EDTA and Rochelle salt were additionally introduced into the system.

The sorption and desorption were studied at a temperature of $20 \pm 1{ }^{\circ} \mathrm{C}$. All used reagents were of analytical grade. Standard aqueous solutions of neodymium and gadolinium nitrate $\left(\mathrm{Ln}^{3+}\right.$ concentration was $1 \mathrm{mg} / \mathrm{ml}$ ) were prepared by dissolving the metallic neodymium and gadolinium (99.9\% purity) in the solution of $\mathrm{HNO}_{3}(1: 1)$.

\section{Results and discussion}

It was found that the sorption efficiency of $\mathrm{Nd}(\mathrm{III})$ and $\mathrm{Gd}(\mathrm{III})$ depends significantly on the acidity of Ln solutions (Fig. 1). The trace amounts of $\mathrm{Nd}$ (III) most effectively are sorbed on the zeolite from the neutral medium at $\mathrm{pH}$ 6.5. However, the best concentration of Gd(III) occurs from the low basic solutions at $\mathrm{pH} 9.5$. It is known [7, 10-13] that OH-groups are predominantly sorption active centers of Transcarpathian clinoptilolite towards heavy metals ions. In our opinion, the sorption process of the studied Ln is caused by both chemical specificity of zeolite surface and dominant forms of $\mathrm{Nd}(\mathrm{III})$ and $\mathrm{Gd}(\mathrm{III})$ species in water solutions at various $\mathrm{pH}$ values. Dissociation of hydroxyl groups on mineral grains surface, which is responsible for sorption of heavy metals ions from the solutions, is almost completely inhibited at low $\mathrm{pH}$ values. This is the reason for low value of clinoptilolite sorption capacity towards $\operatorname{Ln}(\mathrm{III})$ ions. Moreover, at these conditions the competing reaction of ion exchange on protons is taking place. Increasing $\mathrm{pH}$ facilitates the dissociation of surface $\mathrm{OH}$-groups and has a positive influence on the sorption capacity.

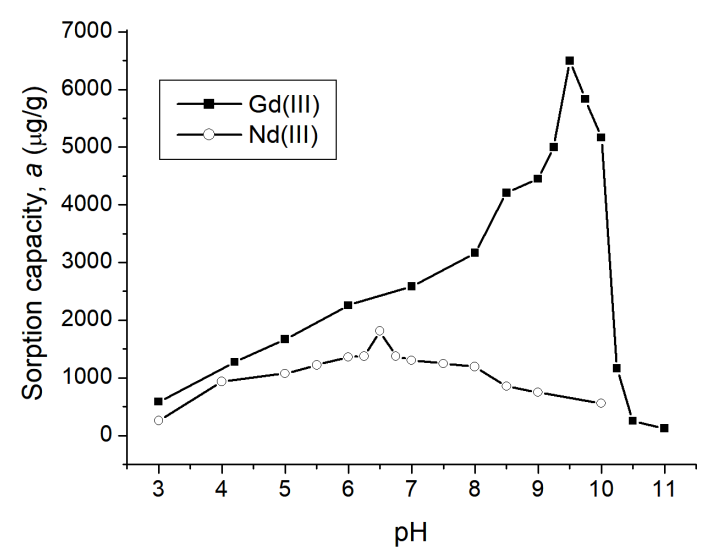

Fig. 1. Dependence of the sorption capacity, $a$, of clinoptilolite towards neodymium(III) and gadolinium(III) on the $\mathrm{pH}$ value of the aqueous solution.

At different $\mathrm{pH}$ values existing forms of $\mathrm{Nd}(\mathrm{III})$ and Gd(III) in the solution are changed. Currently the hydrolysis of $\mathrm{Nd}(\mathrm{III})$ and $\mathrm{Gd}(\mathrm{III})$ is studied poorly. We have carried out the calculation of the distribution of different forms of $\mathrm{Nd}(\mathrm{III})$ and $\mathrm{Gd}(\mathrm{III})$ in aqueous solutions at different $\mathrm{pH}$ values. The system of equations that describes equilibria of $\operatorname{Ln}(\mathrm{III})$ hydrolysis is the following:

$$
\begin{aligned}
\mathrm{K}_{11} & =\frac{\left[\mathrm{LnOH}^{2+}\right]\left[\mathrm{H}^{+}\right]}{\left[\mathrm{Ln}^{3+}\right]} \\
\mathrm{K}_{12} & =\frac{\left[\mathrm{Ln}(\mathrm{OH})_{2}^{+}\right]\left[\mathrm{H}^{+}\right]^{2}}{\left[\mathrm{Ln}^{3+}\right]} \\
\mathrm{K}_{22} & =\frac{\left[\mathrm{Ln}_{2}(\mathrm{OH})_{2}^{4+}\right]\left[\mathrm{H}^{+}\right]^{2}}{\left[\mathrm{Ln}^{3+}\right]^{2}}, \\
\mathrm{C}_{\mathrm{M}} & =\left[\mathrm{Ln}^{3+}\right]+\left[\mathrm{LnOH}^{2+}\right]+\left[\mathrm{Ln}(\mathrm{OH})_{2}^{+}\right. \\
+ & 2\left[\operatorname{Ln}_{2}(\mathrm{OH})_{2}^{4+}\right]+\left[\mathrm{Ln}(\mathrm{OH})_{3}\right], \\
\mathrm{K}_{\mathrm{S}} & \geq\left[\mathrm{Ln}^{3+}\right]\left[\mathrm{OH}^{-}\right]^{3} .
\end{aligned}
$$


droxoform $\left[\mathrm{Ln}(\mathrm{OH})_{3}\right]$ appears. Probably at the negligible total concentration of $\mathrm{Ln}$ the formation of this form will not cause the appearance of a solid phase of the hydroxide and it will remain in a soluble state.

Since it is not known beforehand whether $\operatorname{Ln}(\mathrm{OH})_{3}$ will be formed or not (will the $K_{s}$ condition be fulfilled), the solution of the system of equations was carried out in two steps. At first it was assumed that the condition of $\operatorname{Ln}(\mathrm{OH})_{3}$ formation is not fulfilled, so the equilibrium state was calculated assuming that $\left[\mathrm{Ln}(\mathrm{OH})_{3}\right]=0$. At this stage for each $\mathrm{pH}$ value the equilibrium concentrations of $\mathrm{Ln}^{3+}, \mathrm{LnOH}^{2+}, \mathrm{Ln}(\mathrm{OH})_{2}^{+}$and $\mathrm{Ln}_{2}(\mathrm{OH})_{2}^{4+}$ forms were found. Then for each $\mathrm{pH}$ value the condition of neutral hydroxide formation $\left(\left[\mathrm{Ln}^{3+}\right] \cdot\left[\mathrm{OH}^{-}\right]^{3} \geq K_{s}\right.$ ) was checked. If the condition was obeyed, then the solution was carried out according to all four equations and beside forms mentioned above the equilibrium concentration of $\mathrm{Ln}(\mathrm{OH})_{3}$ was found, too. At conditions of our investigations the concentration of foreign electrolytes did not exceed $0.01 \mathrm{~mol} / \mathrm{l}$, so we used average values of constants for calculations found at the low ionic strength of the solution $(\mu<0.01)$ [14-18]. Graphs with the distribution of different forms of $\mathrm{Nd}(\mathrm{III})$ and $\mathrm{Gd}(\mathrm{III})$ are given in Fig. 2 and Fig. 3. Our calculations show that $\mathrm{pH}$ value, at which the formation of a neutral hydroxide $\mathrm{Ln}(\mathrm{OH})_{3}$ and maximal fractions of charged hydroxoforms are reached, for Gd are bigger, than for Nd (presumably on $0.2-0.3$ ). In general the shape of distribution curves of different forms of metals depending on $\mathrm{pH}$ at various values of the total concentration is similar for both of these Ln. While increasing the total concentration of the metal the formation of $\mathrm{Ln}(\mathrm{OH})_{3}$ begins at the lower $\mathrm{pH}$ value. At the low total concentration of the metal (Figs. 2, 3) the form $\mathrm{Ln}_{2}(\mathrm{OH})_{2}^{4+}$ is practically not formed (the maximal fraction does not exceed $0.045 \%$ ).

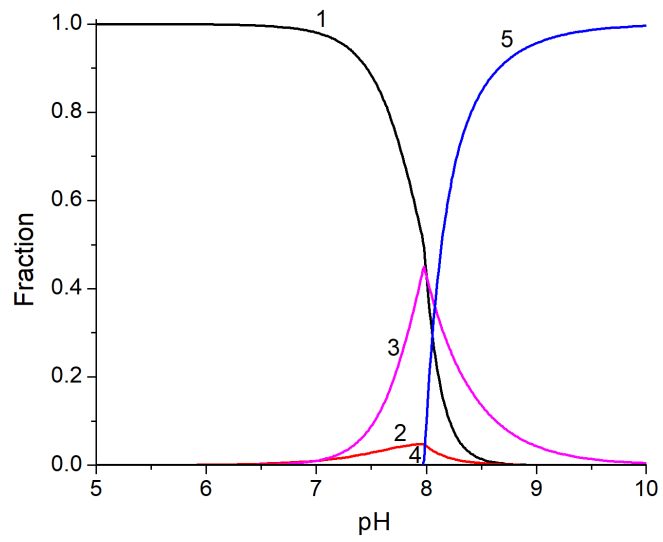

Fig. 2. Dependence of the $\mathrm{Nd}(\mathrm{III})$ species fraction on $\mathrm{pH}\left(1-\mathrm{Nd}^{3+}, 2-\mathrm{NdOH}^{2+}, 3-\mathrm{Nd}(\mathrm{OH})_{2}^{+}, 4-\right.$ $\left.\mathrm{Nd}_{2}(\mathrm{OH})_{2}^{4+}, 5-\mathrm{Nd}(\mathrm{OH})_{3}\right)$.

The trace amounts of $\mathrm{Nd}(\mathrm{III})$ mainly exist in the cationic forms of the aqueous complexes $\left[\mathrm{Nd}\left(\mathrm{H}_{2} \mathrm{O}\right)_{9}\right]^{3+}$ in the solutions at $\mathrm{pH}$ 6.5. Weakly alkaline solutions of $\mathrm{Gd}(\mathrm{III})$ contain the neutral hydroxocomplex $\left[\mathrm{Gd}(\mathrm{OH})_{3}\left(\mathrm{H}_{2} \mathrm{O}\right)_{5}\right](95 \%)$ and a negligible content of the

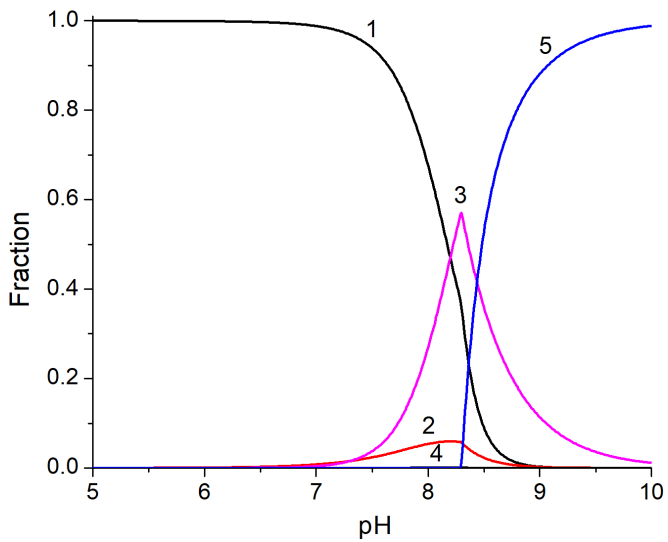

Fig. 3. Dependence of the Gd(III) species fraction on $\mathrm{pH}\left(1-\mathrm{Gd}^{3+}, 2-\mathrm{GdOH}^{2+}, 3-\mathrm{Gd}(\mathrm{OH})_{2}^{+}, 4-\right.$ $\left.\mathrm{Gd}_{2}(\mathrm{OH})_{2}^{4+}, 5-\mathrm{Gd}(\mathrm{OH})_{3}\right)$.

cationic hydroxocomplex $\left[\mathrm{Gd}(\mathrm{OH})_{2}\left(\mathrm{H}_{2} \mathrm{O}\right)_{6}\right]^{+}(5 \%)$ at $\mathrm{pH}$ 9.5. It has been shown that $\mathrm{Nd}$ (III) is sorbed on the clinoptilolite using the ion-exchange mechanism. The sorption of $\mathrm{Gd}(\mathrm{III})$ on this zeolite is generally achieved by means of the adsorption of soluble hydrolyzed forms of $\mathrm{Gd}(\mathrm{III})$ on the surface of the aluminosilicate. The differences on the sorption mechanisms of these Ln give the possibility to separate $\mathrm{Nd}(\mathrm{III})$ and $\mathrm{Gd}(\mathrm{III})$ in the solutions at $\mathrm{pH}$ 9.5. At this optimum condition the clinoptilolite mostly sorbs Gd(III) and practically does not sorb $\mathrm{Nd}(\mathrm{III})$.

The buffer solutions have been used to maintain the constant value of $\mathrm{pH}$, ionic strength of the solutions and to improve the metrological characteristics of preconcentration methods of Ln. In the case of the concentration of $\mathrm{Nd}(\mathrm{III})$ the best results have been obtained with thrys-buffer solution. The trace amounts of Gd(III) most effectively are sorbed with borate buffer solution.

Despite the sorption capacity of the clinoptilolite depends on the temperature of its previous thermal treatment [7, 10-13], Nd(III) most effectively is sorbed at the uncalcined clinoptilolite samples. On the curve showing the dependence of sorption capacity of the clinoptilolite towards $\mathrm{Gd}$ (III) on the temperature of the previous thermal treatment of zeolite samples, two maxima are observed at temperatures of $250^{\circ} \mathrm{C}$ and $500^{\circ} \mathrm{C}$, respectively (Fig. 4). It is known that closest neighbors of $\mathrm{Gd}$ in the periodic table $\mathrm{Tb}$ and $\mathrm{Eu}$ practically do not sorb on the Transcarpathian clinoptilolite calcined at $250^{\circ} \mathrm{C}[12,19]$, that gives a fundamental possibility of quantitative separation of $\mathrm{Gd}$ from $\mathrm{Eu}$ and $\mathrm{Tb}$.

It was determined that the most effective desorbents of Nd from the clinoptilolite are solutions of mineral acids. The solution of $7 \mathrm{M} \mathrm{HNO}_{3}$ provides a $98 \%$ withdrawal of $\mathrm{Nd}$ from the zeolite matrix. $100 \%$ withdrawal of $\mathrm{Gd}$ from the clinoptilolite is achieved by the application of $1 \mathrm{M}$ solution of $\mathrm{KCl}$ as a desorbent, acidified to $\mathrm{pH} 2.6$.

The influence of water macrocomponents on the sorption of $\mathrm{Nd}$ and $\mathrm{Gd}$ on the clinoptilolite was studied, too. Obtained data confirm that the Transcarpathian clinop- 


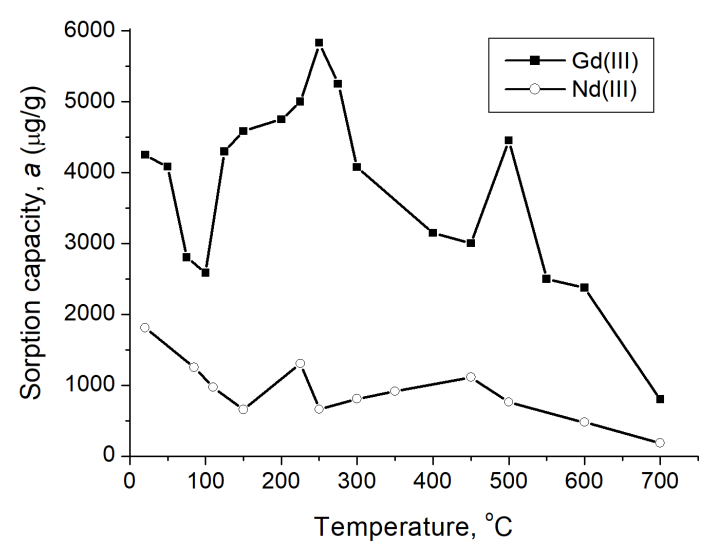

Fig. 4. Dependence of the sorption capacity, $a$, of clinoptilolite towards neodymium(III) and gadolinium(III) upon thermal treatment carried out in the range from 20 to $700{ }^{\circ} \mathrm{C}$.

tilolite could be used for the withdrawal of trace amounts of $\mathrm{Nd}$ and $\mathrm{Gd}$ from aqueous solutions.

\section{Conclusions}

The results of the investigation confirm that the Transcarpathian clinoptilolite is an effective sorbent for the pre-concentration of trace amounts of $\mathrm{Nd}(\mathrm{III})$ and Gd(III) from aqueous solutions.

The optimal conditions for the $\mathrm{Nd}$ (III) sorption on clinoptilolite are the following: flow rate of the solution of $\mathrm{Nd}(\mathrm{III})$ with the concentration of $1.0 \mu \mathrm{g} / \mathrm{ml}$ through the sorbent $-5 \mathrm{ml} / \mathrm{min}$, grains diameter of the zeolite $0.20-0.31 \mathrm{~mm}, \mathrm{pH} 6.5$. The maximal sorption capacity of the clinoptilolite towards $\mathrm{Nd}(\mathrm{III})$ is equal to $1810 \mu \mathrm{g} / \mathrm{g}$. The best desorbent of $\mathrm{Nd}$ is the $7 \mathrm{M}$ solution of $\mathrm{HNO}_{3}$, by means of which $98 \%$ of $\mathrm{Nd}$ concentrated on the zeolite can be desorbed.

The optimal conditions for Gd(III) sorption on clinoptilolite are the following: the temperature of preliminary thermal treatment of $250^{\circ} \mathrm{C}$; flow rate of the solution of $\mathrm{Gd}(\mathrm{III})$ with the concentration of $1.0 \mu \mathrm{g} / \mathrm{ml}$ through the sorbent $-5 \mathrm{ml} / \mathrm{min}$; grains diameter of the zeolite $0.20-0.31 \mathrm{~mm} ; \mathrm{pH} 9.5$. The maximal sorption capacity of clinoptilolite towards $\mathrm{Gd}(\mathrm{III})$ is $6500 \mu \mathrm{g} / \mathrm{g}$. The most effective desorbent of $\mathrm{Gd}$ is a $1 \mathrm{M}$ solution of $\mathrm{KCl}$, acidified to $\mathrm{pH} 2.6$, by means of which $100 \%$ of $\mathrm{Gd}$ is desorbed from the zeolite matrix.

It was found that $\mathrm{Nd}(\mathrm{III})$ is sorbed on the clinoptilolite according to the ion-exchange mechanism, and the sorption of $\mathrm{Gd}(\mathrm{III})$ is achieved mainly by means of the adsorption of the soluble hydrolyzed forms of Gd(III) on the aluminosilicate surface. The differences on the sorption mechanisms of these Ln give the possibility to separate $\mathrm{Nd}(\mathrm{III})$ and $\mathrm{Gd}(\mathrm{III})$ in solutions at $\mathrm{pH}$ 9.5.

\section{Acknowledgments}

This work was partially funded by the Ministry of Education and Sciences of Ukraine.

\section{References}

[1] M. Majdan, A. Gladysz-Płaska, S. Pikus, D. Sternic, O. Maryuk, P. Sadowski, J. Mol. Struct. 702, 95 (2004).

[2] E. Falabella, S. Aguiar, V.L. Doria Camorim, F. Maria Zanon Zotin, R.L. Correa dos Santos, Micropor. Mesopor. Mater. 25, 25 (1998).

[3] M. Ryo, Y. Wada, T. Okubo, Y. Hasegawa, S. Yanagida, J. Am. Chem. Soc. 122, 8583 (2000).

[4] J. Rocha, L.D. Carlos, Curr. Opin. Solid State Mater. Sci. 7, 199 (2003).

[5] A. Godelitsas, T. Armbruster, Micropor. Mesopor. Mater. 61, 3 (2003).

[6] P. Misaelides, A. Godelitsas, S. Harrisopoulas, I. Anonsis, J. Radioanal. Nucl. Chem. 247, 325 (2001).

[7] V.O. Vasylechko, G.V. Gryshchouk, L.O. Lebedynets, Yu.B. Kuz'ma, L.O. Vasylechko, V.P. Zakordonskiy, Adsorpt. Sci. Technol. 17, 125 (1999).

[8] Yu. Tarasevich, V.E. Polyakov, V.Zh. Penchev, G.N. Kirov, Kh.I. Minchev, I.G. Polyakov, L.I. Badekha, Khim. Technol. Vody 13, 132 (1991).

[9] V.O. Vasylechko, L.O. Lebedynets, G.V. Gryshchouk, Yu.B. Kuz'ma, L.O. Vasylechko, T.M. Bernats'ka, Adsorpt. Sci. Technol. 14, 267 (1996).

[10] V.O. Vasylechko, G.V. Gryshchouk, Yu.B. Kuz'ma, V.P. Zakordonskiy, L.O. Vasylechko, L.O. Lebedynets, M.B. Kalytovs'ka, Micropor. Mesopor. Mater. 60, 183 (2003).

[11] V.O. Vasylechko, Ch.B. Korpalo, G.V. Gryshchouk, Solid State Phenom. 237, 8 (2015).

[12] V.O. Vasylechko, G.V. Gryshchouk, V.P. Zakordonskiy, I.O. Patsay, N.V. Len', O.A. Vyviurska, Micropor. Mesopor. Mater. 167, 155 (2013).

[13] V.O. Vasylechko, G.V. Gryshchouk, V.P. Zakordonskiy, O.A. Vyviurska, A.V. Pashuk, Chem. Centr. J. 9, 45 (2015).

[14] L.N. Usherenko, N.A. Skorik, Zh. Neorgan. Khim. 17, 2918 (1972).

[15] V.V. Aksel'rud, Usp. Khim. 32, 800 (1963).

[16] V.A. Nazarenko, V.P. Antonovich, Ye.M. N'evskaya, Hidroliz Ionov Metallov v Rasbavlenykh Rastvorakh, Atomizdat, Moscow 1979 (in Russian).

[17] C.F. Baes, R.E. Mesmer, The Hydrolysis of Cations, Wiley, New York 1976.

[18] E.N. Rizkalla, G.R. Choppin, in: Handbook of Physics. and Chemistry of Rare Earth, Eds.: K.A. Gshneider Jr., L. Eyring, Vol. 15, Elsevier, Amsterdam 1991, p. 393.

[19] V. Vasylechko, G. Gryshchouk, M. Derev'yanko, Ya. Skorobagaty, O. Tymoshuk, Visnyk Lviv. Univ. Ser. Khim. 49, 170 (2008). 